\title{
The new Africa and Brazil in the Lula era: the rebirth of Brazilian Atlantic Policy
}

\author{
A Nova África e o Brasil na era Lula: \\ o renascimento da política atlântica brasileira
}

JOSÉ FLÁVIO SOMBRA SARAIVA*

Rev. Bras. Polít. Int. 53 (special edition): 169-182 [2010]

The main purpose of the present text is to present a relevant regional dimension regarding Brazil's international insertion during the Lula era. Africa has been one of the major fronts of Brazilian international insertion over the first years of the $21^{\text {st }}$ century. The African continent has a significant historical weight in our constitution as a nation and is also part of the moves adopted by Brazil's foreign policy. Brazil decided to play in the new political "chessboard" in which the international context of post-Cold War world consists.

The government headed by President Lula (2003 - 2010) revived in more permanent bases Brazil's foreign policy towards Africa. This new measure seems to be closer to a State policy and tends to overcome some of the reasons for historical oscillations considering Brazil's path in the South Atlantic area. Idealism and realism are gathered in an extremely balanced way supporting the foreign policy conducted by our national State in relation to its Atlantic boundaries.

In this sense, the present work is divided in two parts: the first part approaches Africa's international insertion throughoutthe recent years and the second one is oriented to analyze the dimension occupied by African affairs in Brazil during the Lula era. The historical evolution described on the second part is crucial to emphasize what is novelty about the current relationship involving Brazil's Atlantic borders and its different perspectives.

\section{A new Africa coincides with a global Brazil}

International circumstances experienced during the turn to the present century have been extremely favorable to Africa's international insertion. Years separating 1999 from today represent almost one decade of struggle and obstacle overcoming. Compared to the previous four decades, marked by low economic continuity, fractures in the formation of national States and very low social

\footnotetext{
* Professor at University of Brasília - UnB, Brazil, and researcher of National Council for Scientific and Technological Development - CNPq (fsaraiva@unb.br).
} 
standard levels, there is a new Africa represented by the relatively successful results experienced over the first decade of the $21^{\text {st }}$ century.

Noticeable economic development in a recent cycle (1999-2008) has brought structural consistency to the modernization of the African continent, which comprises a territory of thirty million square meters. This is truly a novelty in African states' recent history, born as a result of the first series of independence processes happening by the end of the 1950's and beginning of the 60's.

All quantitative and qualitative data produced by international agencies, as well as the rulers of the fifty-four African States, have brought about significant empirical evidence concerning initial assertions. Economists, governments, as well as Chinese and American companies, and even balance sheets carried on by Brazilian companies and government entities, have confirmed the historical improvement witnessed over the other side of the South Atlantic in the early $21^{\text {st }}$ century.

Nearly 700 million Africans now behold a new hope for normalization, after decades of turmoil, structural crises and historical difficulties in the fields of social asymmetry and economic dependence on their former metropolises. Acknowledged as global capitalism's last investment frontier, Africa has recently captured the attention of the international community. This has been Africa's opportunity to, through economic growth, pursuit political normalization as well as to promote the pacification of its internal conflicts such as the ones held among the different National States within the continent.

The expectations which made Africa prominent in the international system have been extremely relevant considering a continent dwelled by States counting only half a century of formal autonomy after the colonial cycle. It's likely that over the first decade of the present century, Africa has been overcoming the historical drama regarding its internal wars and political violence. Despite the gravity properly applied to the case of Darfur, the number of African countries involved in internal armed conflicts decreased from 13 to 5, between 2001 and 2008. These conflicts have been the most important immediate cause of the high poverty levels in the continent. Their drastic reduction suggests that resources, an estimated amount of US\$300 billion spent in the wars between 1990 and 2005, may now be directed to poverty eradication policies.

The new setting in international affairs over the second semester of 2008 and first half of 2009, especially regarding the economic fields, has called the attention of African leaders and made them reflect. The initial concern was that the global economic crisis would reach the periphery of capitalism, especially most African countries, resulting in a "domino effect", following the pattern of instability originated in North-American capitalism and its European extensions.

The crisis, born due to capital toxicity, the most relevant global fact in the second half of 2008 after its migration to productive activities by the end of that year, became more serious and was already geographically widespread. This crisis 
intensifying in the first months of 2009 was no surprise to the ordinary observers of global affairs.

Had the crisis stricken the whole world? The logic in which each new economic index is presented by government authorities in different parts of the planet frustrated the initial hope. Fatalism was intense and had proportionally reached the other villainous logic that prevailed in a relatively recent historical paradigm: the one marked by euphoric triumphalism from the ones who had declared the "End of History" in the early 90's, followed by the rise of "a liberal paradise".

There was somehow panic in Africa. It was soon noticed that the context was not as atrocious as it was believed to be. Eventually, Africa had not been completely affected by the congenial pessimism previously witnessed. There the context was slightly different from what it is likely to be in capitalism's traditional areas and in the most prominent part comprising the emerging countries in the South. Macroeconomic normalization rates are rather positive, public management has improved and African economies have not been as much affected as were some central areas of modern capitalism. The continent is still living a cycle of growth. And this development has been considered the most sustainable one since the independence movements in early 1960's. Moreover, the 2010 Soccer World Cup was an effort in order to improve the negative values attributed to the continent and turn them into a positive perspective. South Africa represented, through the soccer championship, the yearning of a whole continent.

Naturally, Africa is not totally immune to global crises. Chinese retraction has caused some impact over the continent. However, the advancement of capitals coming from the Persian Gulf has compensated credit and infrastructural financing of some new projects headed by NEPAD, enabling the African initiative regarding sustainable development and social incorporation of the ones seen as more vulnerable.

Despite the effect of a pessimist fever contamination, Africa is one of the very few parts of the planet in which the talk on crisis has not acquired a relevant proportion. Partly, due to the fact that the crisis has been a lasting picture considering African geography. The continent has been a "laboratory" testing the most inadequate models of development, citizenship matters as well as the continent's autonomy and decision-making power, for several years in a row. Now what they wish to have Africa for the Africans, what has somehow been seen as a kind of Monroe Doctrine on the other side of the South Atlantic. There has been a huge feeling of pride comprised in the talks of continental Africanity held in South-African stadiums during the last the 2010 Soccer World Cup.

For the pessimists, it's only possible to talk about Africa in turmoil times which generated real humanitarian tragedies or in times of corrupt governments. In fact, these matters deserve total attention and care from international public 
opinion, but there are certainly other "Africas". There are "Africas", acknowledged by North-American Freedom House's reports, which have reduced conflicts and enabled the advancement of "free" political regimes.

Besides the situation in Darfur, Congo, the case of Somali pirates or Zimbabwe's previous regime, or even despite corruption problems in South Africa, more than $50 \%$ of current African governments are considered democratic or witness a process of democratic normalization. President Obama is aware of this fact and is known to have his plan for Africa. Brazil, currently ruled by President Lula, began its adequate inflection towards Africa way before.

There are even some important lessons learned from Africa. Angola's economic growth rate, which has proven to remain among 7\%, is a very auspicious fact. Such growth is also noticed in Eastern Africa, Ethiopia and Ghana, located in Guinea's Atlantic Gulf. The same could be applied to what happened in Northern Africa, to the Algerian case, anchored on oil and on a project of economic and political leadership in the region.

Despite the fact that the continent was not stricken by the crisis as announced by many defeatist heralds, Africa is still haunted by ancient challenges which do not evolve on the same path of its integration in the global society. Four main challenges, among others, can be named and developed into relevant themes for reflection for the next few years in Africa.

The first are the low rates of alternation in power within the continent. The lack of electoral alternation in not a novel theme, but it presents new outlines over the second decade of the current century. These dubious regimes and governments, going through a very slow institutionalization process, unhurriedly substitute the precedent rulers for other elites, which are more refreshed and modernized.

The second challenge is penetration of international narcotraffic within Africa, considering the constitution of new elites and other sectors of urban populations in the continent's metropolises. This is a relatively new aspect rooted in the ancient resource wars in Africa, or the well-known blood diamond wars, like the ones in Western Africa and in Angola, now presenting new versions.

There are growing concerns with respect to the so called "African bridge", emerging between Latin America and Europe, involving people and drug smuggling. There is strong evidence of international trafficking corridors, which associate coca paste producers in South America to the transportation and preparation of new products in West Africa and its manipulation process in Africa and Europe.

There are few available data with regard to this subject. However, they seem to be enough to form an assumption that those interests, a reality in international political economy, are vivid in Africa's current economic and political affairs. What has been noticed is the rise of parasite states, directly attached to this international threat. 
The third challenge is placed in the exclusive field of public policies conducted so that they can improve financial gains attained over recent years, emerging from capitalism's highest rates of development in its history. It is also known that this wave's balance has been broken and that global economic growth is on its way to be reestablished and tends, modestly, to follow its path for many years. This has great implications towards African public policies aiming sustainable development as well as social inclusion.

The new order emerging before the end of what was considered a "golden decade", presenting a more modest economic growth, will demand important choices coming from African leaders and society members. If back in 2007, before the impact caused by the global international crisis, 37 African countries (almost two thirds of all continental nations), used to grow beyond $4 \%$ a year, and 34 were classified by Freedom House as free or partially free, how can this pace be kept within a context marked by less capital available to be invested in Africa over the next decade?

Besides the ancient challenges, which remain resilient in Africa's recent history of international insertion, difficulties associated to the changes in progress in the international order linger. Africa will need an élite showing more commitment concerning decision-making autonomy and a positive integration of the continent to global economic processes, as well as a balance between moral and power, and among interests and international cooperation on the $21^{\text {st }}$ century.

African economists and Africanists claim that the economic growth witnessed by Africa along the first golden decade of the $21^{\text {st }}$ century is not likely to follow previous patterns. Although Africa, according to OCDE, has been receiving more resources coming from investments than from international aid, this equation may be inverted if there is not responsibility from the part of its rulers within this important chapter of economic normalization already held in Africa despite serious internal costs.

Inflation control and fiscal responsibility have been important moves on macroeconomic normalization headed by African governments in the African continent by the end of the 1990's and beginning of 2000's. The throwback in these fields and the re-establishment of the external debt cycle would be fatal considering the partial improvements achieved so far.

The fourth and last challenge to be faced by Africans in the coming years in the temptation to, considering possible new difficulties rising from the international front, make use of victimhood excuses. This argument, of great political efficacy for African wicked elites, does not fit the Africans who build their future based on their daily lives.

Africa has proven that even humanitarian initiatives, like the aid provided in the 1990's, have brought very few practical advantages to the target population, and have eventually reinforced power schemes ruled by elites. External aid, attached by extreme ties with predominant elites, who contribute to intensify 
social, economic and political differences, is a conspiracy against Africa in the sense that the continent tends to remain infantilized in some sectors due to this kind of false pity.

\section{Brazil's action in Africa during the Lula administration and some historical background}

During the golden decade of economic growth, which comprises the first ten years of the present century, Brazil increased its participation in investment, commercial presence, creation of new embassies and on its strategic and political weight in the African continent. Brazil has gained ground in its Eastern borders. What happened was the replacement of a silent period in its relationship with Africa for a cycle of cooperation and common altruistic projects for the other side of the South Atlantic.

There are ancient ties which attach Brazil and the African continent. In actions and mental constructions, Africa became a participant in institutions, economy, multiple identities and in the culture in Brazil. Slavery and slave traffic over the Atlantic have surely initiated this common history, which attached Brazil and Africa from the $16^{\text {th }}$ century up to the end of the $19^{\text {th }}$ century.

There was also a historical construction that affected diplomacy and Brazil's international relations during the second half of the $20^{\text {th }}$ century. The relations between Brazil and Africa tended to have a minor role in the nationaldevelopmentist foreign policy adopted by President Vargas as well as the following governments.

There's a certain consensus that establishes that the rebirth of Brazil's foreign policy towards Africa started in early 60's, during the administrations of presidents Jânio Quadros (1961) and João Goulart (1961-1964). This would have been a natural consequence of the independence process of most African Countries between 1957 and 1960. However, the analysis of diplomatic documents available on the economic reports, as well as the parliamentary papers, prove that the initial elements of Brazilian policy towards Africa have their origin between the end of the 40's and beginning of the 50's.

Among the themes directly referring to Africa considered by Brazilian diplomacy between 1946 and 1961, it is important to highlight: international investment in the development of Latin America and Africa, the competition between Brazilian and African primary products in the international market, the perspective of partnership between Brazil and South-Africa, the special liaisons involving Brazil and Portugal through the Luso Brazilian community, and eventually, the first consequences of African decolonization in the South Atlantic area.

Brazil left World War II decided to expand its industrialization and to conquer a certain regional influence. This is the basis of the inclusion of Africa 
in the country's international agenda, initially as a minor actor and later, in the 1950 's, as a growing element of interest.

Nonetheless, the origins of the most classic model of the Brazilian policy towards Africa must be particularly identified in the 1960's, considering the Brazilian effort to promote economic development. Brazil's approach towards Africa has been permeated for ideological representations of the role Brazil would have in the future of Africa. Brazil's natural vocation regarding that continent was equally an important component of the rising policy, which found adepts and skeptical inquirers. The governments ruled by Jânio Quadros and João Goulart, considering the context of independent foreign policy, have been the basis to the acceleration of a policy based on the support of the numerous independence processes, which started to blossom in Africa. Itamaraty, in particular, sent a great number of missions and established in that continent the first Brazilian embassies.

The period that ranges from 1964 to 1969 is, in a general way, a moment of oscillation in the liaisons involving Brazil and Africa, when compared to the improvement noticed in Quadros and Goulart's Independent Foreign Policy. But the drawback did not mean a complete relinquishment of Africa. In a way it substituted the emphasis in the political and economic cooperation with Africa for the geopolitical approach, a concept in complete synchrony with the new forces ruling Brazil after the 1964 coup d'état. This happened, in special, due to the restoration of the liberal standards associated to the administration of President Castelo Branco (1964-1967) and its emphasis on internal and external defense against the communist threat.

The necessity of adjustment with the Western world, in the fashion of interdependence, placed Brazil's foreign affairs at the service of the traditional alignment with the United States, as previously during President Dutra's administration.

The third military government $(1969$ - 1974) explicitly promoted the reanimation of the relations with Africa. This flow was reinforced during the fourth and fifth military administrations (1974-1985), and remained influent during the first civilian government and the transition to democracy (1985-1990). The signs of this re-establishment had existed since the "Prosperity Diplomacy" times, but its reassurance had only reappeared more clearly during Médici's government. The Foreign Minister of Brazil, Gibson Barbosa and his visit to nine countries in Black Africa (1972) was the most evident demonstration of the official efforts to reach Africa and symbolized the reactivation of Brazilian Diplomacy towards it and the goals to readapt the African continent into Brazilian markets. At the same time, the African policy had its own function in the conservative project of modernization of military governments considering national development and the growth of Brazil's autonomous role in the international system.

Brazil's insertion in international relations during the 70's led the country to reinforce cooperation with Black Africa, especially with Nigeria; as well as 
to develop a cooperation policy with the new socialist countries in Africa; and to review the traditional cooperation with South-Africa; and especially to end the alignment with Portugal and is colonialist interests in Africa. The official recognition of Angola's independence in 1975 was the climax amid the new standards of international relations between Africans and Brazil.

Brazil's foreign policy towards Africa at the given period, used to have four principles that are enough to justify it. Firstly, it was intimately associated with the maintenance of the national developmentist project (expansion and modernization headed by the State) through an aggressive and effective international strategy.

Secondly, the core of international affairs between Brazil and Africa used to be economic and commercial pragmatism. At the same time its vulnerability on energy sources led Brazil to include an oil supply policy through Africa.

Thirdly, Brazil kept, through African policy, its influence over the South Atlantic area. The South American giant also developed its interests via the stimulation of economic relations in a peaceful fashion, without the militarization of that region, or direct interference of other internationally powerful countries or security pacts with South Atlantic Treaty Organization (SATO). This represented the end of geopolitical calculations and the rise of a modern strategic conception.

At last, Brazil built new ties with countries presenting Portuguese expression, but that were not attached to the traditional Luso-Brazilian Community. The defense of common culture and history started to take place through a direct and independent cooperation system with the above-mentioned in Black African countries.

The institution of a pragmatic foreign policy directed the governments of Médici and Geisel to criticize the distribution of power in the international system, which, for them, would harden the possibility of appearance of new power poles such as Brazil. This implied direct criticism towards the United States. At the same time, it relocated Brazilian strategy to search new partners in the international system and the diversification of contacts without taking into account the ideological frontiers which used to be so relevant to Castelo Branco's administration. The expansion of trade involving Brazil, Africa, the Middle East and Latin America was one of the most important changes happening in the field of foreign economic affairs in the 1970's and part of the 1980's. Brazilian exports to third world countries increased from $12 \%$ in 1967 to $26 \%$ eleven years later. In 1981, for instance, Brazil sold $52 \%$ of its manufactured exports to the Third World against $46 \%$ sold to Northern industrialized countries.

Brazil's new perspectives were a result of the growing complexity of the international system itself, which ranged from a rigid polarization to a relative decrease in the power of The United States in the Western system, as well as the rise of important rivals such as Japan and Western Europe. The uncertainties of the international scenario demanded a more flexible and pragmatic action on the part of Brazilian diplomacy. 
Africa turned out to have more functional and supplementary relevance to Brazil's foreign policy. Politically, the African continent used to be a potential source of support to common demands in the dialogue between North and South, in the UN, as well as in other multilateral entities. Economically, the previous policy could be translated into mutual economic interests serving Brazilian pragmatism. Simultaneously, the country's energy supply vulnerability went on being a huge concern to the rulers of Brazilian foreign policy in the 70's and part of the 80's. Nigeria and Angola were oil suppliers, and, in a certain way, represented to Brazil a spot of diversification away from its own vulnerability.

The new objectives designed by Brazil towards Africa turned out to be better defined: a) to project the image of a tropical industrial power and b) to convince African States that the liaisons established between Brazil and Portugal should not inhibit the development of an intense relationship with the now independent Black Africa.

The pursuit for new markets, especially for manufactured goods, was also well accepted by the strategist military sectors, which had spoken almost exclusively in terms of Brazil's military hegemony in the South Atlantic. The importance of the South Atlantic as a vital area was maximized by the necessity of increasing oil imports and exports. More than $90 \%$ of Brazilian trade was transported, as it is nowadays, through the sea, especially by Cape Route, surrounding South Africa.

President José Sarney (1985-1990) also kept the standards towards Africa previously defined by Geisel and Figueiredo during their administrations. The approach was that there was no reason to change foreign policy during the transition from an authoritarian to a democratic regime. Brazil's African policy had acquired a peculiar consistence and diffusion in many areas of political society in the surroundings of the South Atlantic. Still during Sarney's administration, Brazil reinforced criticism to apartheid editing Law no 91.524, in August 9 $9^{\text {th }}, 1985$. The new canon imposed sanctions against South Africa. It was exactly during Sarney's administration that Brazil headed, in the United Nations, the movement in favor of the resolution that eventually declared, in 1986, the South Atlantic as a zone of peace and cooperation. This act ended up confirming the dimension of Brazil's policy towards Africa carefully assembled since the end of the 1970's during the administration of President Figueiredo, in order to avoid South Africa from establishing a regional security, in a way, similar to NATO.

There were several obstacles to Brazil's economic presence in Africa. Firstly, there was a variety of markets and a great number of discrepancies in the capacity to consume among African economies. Brazilian companies had to face cultural diversity, the lack of new interlocutors, and the different government languages.

The second obstacle was Africa's low industrialization levels. The continent used to have a very limited number of manufactured goods able to be introduced in Brazilian markets. There was also a significant limitation of credits for exporting in those countries. 
The third barrier was probably the most crucial. Brazilian trade had to face the privileged relationship kept between African economies and their former metropolises. Those markets had been engrossed since colonial times and preferential deals between African producers and the European Economic Community had been signed at the time of Africa's emancipation. The most serious consequence originated from the traditional alliance between African producers and European markets was that transportation, freight and financing were directed exclusively to Europe.

The 1990's were marked by equidistance between Brazil and the African continent. The president elected in 1990 managed to reinforce the ties with the developed countries. Collor de Mello, promising to lead Brazil, once again, through the paths of development and modern capitalism, decided to push Africa aside and reinforce liaisons preferably with developed Western economies. He tried to recover the original standards of associated liberalism in his declarations and first actions as a ruler, but soon Collor had to surrender to the strength of nationalism and a whole diplomatic tradition of partner-countries diversification, which was the basis of Brazilian foreign policy. This is essential in order to understand Fernando Collor de Mello's trip to four Southern African countries in September, 1991 reproducing the same speech which had been the basis for the relationship between Brazil and Africa during the previous decade.

Anyway, the decreasing trend was evident. The economic crisis in Africa in early 1990's became more serious than the crisis striking Latin America. African markets tended to be more reduced as well the region's influence in the transition of a post cold war world. Brazil, on the other hand, was no longer facing energy shortage, a fact that in the past had triggered the country's policy regarding Africa. This way, the levels of trade established between Brazil and Black Africa had returned to the numbers registered in the 1950's and 60's. In the 1990's, trade between Brazil and Africa would not reach $2 \%$ of the first country's commercial relations amount, after having reached around $10 \%$ in early 80 's.

The low rates did not necessarily mean the end of the contracts and deals. Brazil maintained its presence in Africa, particularly in the economic field, because some companies had decided to remain in the continent. There was also the rise of a new identity in the field of political agreement, especially since the end of apartheid in South Africa in 1994. Foreign policy towards Africa would remain in a more selective way, with specific and numbered priorities in the continent. The great extent of the policy towards Africa in the 1970's and part of the 1980's had been replaced by a more limited focus which included very few countries, regions and themes.

The changes regarding African dimension in the international insertion of Brazil were noticed in the initiatives during President Inácio Lula da Silva's first trips to a number of countries in Southern, Central, Atlantic and Northern Africa in 2003 and 2004. This way, there was evidence of a new political will 
which aimed the inversion of the picture of oscillation and inconsistence of the 1990 's. But the initiatives did not bring immediate results so that Brazil's good will towards Africa was acknowledged once Africans were already used to gestures based on advancements followed by several drawbacks from the part of Brazil.

According to Brazilian public opinion, the most important of president Lula's disembarks were the ones to sub-Saharan Africa. The first visit happened in the end of 2003 when the president visited Angola, Mozambique, South Africa, Namibia and São Tomé and Príncipe. The second was the journey to São Tomé and Príncipe, Cape Verde and Gabon, in 2004.

In both cases the president was accompanied by a huge delegation, including a number of ministries, entrepreneurs and intellectuals. In Brazil, the trip was seen as a symbolic gesture and the rebirth of a new cycle comprising our relationship with South Atlantic countries. Nevertheless, other heralds highlighted the scarce possibilities for a renewed agenda including that continent, once it had been dominated by collective tragedies and economic and social underdevelopment.

The fact is that the revival of Brazil's African policy by the beginning of the 21st century has been held in a new background. Firstly, there is a coordinated strategy based on national interests and its protagonists, including entrepreneurs in charge of the expansion of Brazilian capitalism and diplomatic agents. Undoubtedly, a political fact that can be considered a landmark to the rebirth of this policy was the Brazil-Africa Forum: Politics, Cooperation and Commerce, held in Fortaleza, in may, 2003, which provided a strategic closure to the decision process.

There are conceptual, as well as practical, innovations considering the reactivation of Brazil's Eastern surroundings as one of the preferable regions for contacts, cooperation and trade. One of them is the re-examination of the previous "culturalist" speeches in favor of a more structural and pragmatic approach regarding the cooperation with African elites. Consequently, there is a reconsideration of traditional themes concerning Brazilian "Africanity" and its connection with the idea of an assertive foreign policy towards Africa.

Lula, along with the Brazilian diplomacy, has innovated considering the country's proximity with the African continent. This was, partly, the end of the traditional culturalist speech that had historically permeated the inflections involving Brazil and Africa. This concept was replaced by another talk: the one based on Brazil's historical debt in relation to Africa. The moral debt, acknowledged not only by the president, but also by a great part of Brazilian society, demands a new form to constitute the country's foreign policy.

The second conceptual dimension is its character, against the merely instrumental function previously noticed in the field of the liaisons between Brazil and Africa already scrutinized along this chapter. The renewed policy towards Africa was made more public and legitimated by a social and political consensus in Brazilian society, through institutions such as the parliament, universities, African-Brazilian groups, companies and public opinion most interested agents. 
If Africa is a privileged source for the formation of a Brazilian identity, cultivated and developed as time goes by, a policy for the African continent could not obliterate such particularity. This way, the identification of contemporary African leaderships advocating a new discourse towards Brazil has presented extremely different images compared to the ones previously formulated by Brazil in Africa.

In previous decades, Brazilian politicians, military agents and entrepreneurs, made use of what was then known as cultural solidarity, most of the times without the African part's acquiescence. In many aspects this expression caused a series of illusions. We believed we used to have a natural place or position in Africa, that we were the only way to bridge metropolitan Europe and extremely poor Africans, as reminded by President Jânio Quadros during the initiatives of revival of Brazil's African policy in early 60's.

These symbols are a novelty concerning Brazilian foreign policy and must be celebrated. There is a clear reversion in the illusions which once considered Brazil a racial democracy, able to function as a role model to Africa, in favor of a more multicultural country, which has numerous similarities with African social realities.

However, the words and gestures did not remain in theory. The practical attitudes applied to Africa were the redesign of a way to collaborate with the agenda of sustainable development towards our Atlantic surroundings. Africans do not want to find in Brazil anything related to a possible historical forgiveness. This has been extremely clear through the speech analysis of African intellectuals and diplomatic agents. What they want is to talk about the future and about the possibilities for Brazil to contribute to that continent's sustainable development.

In this sense, the new foreign policy adopted by Brazil towards Africa in the beginning of the $21^{\text {st }}$ century is not a re-edition of the past. It's bolder in order to inhibit international assistencialism, disguised in the most varied forms of old fashioned technical cooperation, so that it will be part of the reconstruction of a logistic and productive infrastructure in Africa. It also encompasses a dimension related to citizenship and acknowledgement: the cooperation programs aiming to combat AIDS, the experiences involving SEBRAE, EMBRAPA's expertise, among other several companies from Brazil, which have been active in a number of African countries over the last years.

Considering foreign policy matters, Brazil has been working with Africa in favor of a South-South adjustment so that it is possible to build a common platform of interests. The mutual access involving Brazil and Africa and agricultural products in Northern markets has been defining interests on international negotiations. From Doha to Cancún and considering the establishment of G-20, Brazil has become a huge representative of African affairs in the international system.

IBSA (India, Brazil and South Africa) has been prodigious regarding cooperation in aspects of interest in a multilateral world. This forum has served as tripartite power regarding international relations in the South. Defense services, 
business companies, social communities and intellectuals converge on mutual knowledge and practical experiences of interaction; smaller businesses follow the model established by SEBRAE, among other markedly varied aspects.

In the economic field, and besides the crisis experienced by the end of 2008 and beginning of 2009, Brazil has collaborated with Africa in the sense of a positive outcome, which is a sign of global economic recovery and of the logistic concept of the domestication of globalization through the reinforcement of the State's inductive character. This is noticed considering mutual initiatives of multilateral economic entities.

Regarding bilateral and interregional perspectives, the association between Brazil and Africa in South-South cooperative projects, involves direct investment from Brazilian companies operating in African countries in a more state-of-theart actuation; this trend does not reinforce what used to be called a third world culture, but on the contrary, is deeply inspiring to Brazilians and Africans. Such association, in a certain way, was noticeable on WTO (World Trade Organization) conference in Doha; it was more widely discussed during the following conference in Cancún, and while most recent negotiations took place, in Geneva, Brazil and India represent the G-20 in the reversion of protectionist agricultural policies in hegemonic countries. These are victories, which should not only be attributed to Brazil or the hugest agricultural countries, but also to the smaller cotton producers in Africa, for instance.

This new trend involving Brazil and Africa in which the initiative to act in a collective way prevails, is what Africans crave for. It's a way that has been demonstrating its effectiveness and that clarifies what can still be done, in such a coordinated action, based on the idea of a sustainable development. The findings resulted from the General Assembly of UNCTAD in Rio de Janeiro (2004), in the same context where Africans and Brazilians celebrated their achievements in new rounds of international trade against hatred subsidies to European and North American producers; this context tends to advocate that a new South is rising, forming anti-hegemonic coalitions in which Brazil and a number of African countries have been taking part of.

From the viewpoint of global themes, this practice to work along with Africans allows Brazil to envision to the possibility of designing a common plan for social and economic development of their populations as well as entitling a new ground for Brazil and Africa among the other nations.

This way, it is right to conclude that the Lula era helped to structure a policy based on permanence and continuity along its Atlantic border. This has been an extremely positive achievement considering Lula's eight years ahead of Brazilian government. This virtuous circle is expected, at a certain level, to express the political maturity achieved by a State policy aimed at South Atlantic countries and go beyond a mere passing fad. 


\title{
Bibliographical references
}

RODRIGUES, José Honório. Brasil e África. Outro horizonte. Rio de Janeiro: Nova Fronteira, 1982.

SARAIVA, José Flávio Sombra. Formação da África Contemporânea. São Paulo: Editora Atual/Unicamp, 1987.

SARAIVA, José Flávio Sombra. O lugar da África. A dimensão atlântica da política externa do Brasil. Brasília: Editora da UnB, 1996.

SARAIVA, José Flávio Sombra. Política exterior do governo Lula: o desafio africano. Revista Brasileira de Política Internacional, 45 (2), 2002, pp. 5-25.

SARAIVA, José Flávio Sombra (org.) Comunidade dos paises de língua portuguesa (CPLP): Solidariedade e ação política. Brasília: Instituto Brasileiro de Relações Internacionais, 2001.

COELHO, Pedro Motta \& SARAIVA, José Flávio Sombra (org.) Fórum Brasil-África: Politica, cooperação e comércio. Brasília: Instituto Brasileiro de Relações Internacionais, 2004.

Received August 11, 2010 Accepted November 11, 2010

\begin{abstract}
In the post-Cold War world, Africa has been an important focus of Brazilian foreign policy. Having a significant historical weight in building our nation, African countries are also part of the moves adopted by Brazil's foreign policy. The main purpose of the present text is to show this relevant regional dimension regarding Brazil's international insertion during the Lula era. The work is divided in two parts: the first part approaches Africa's international insertion throughout recent years and the second analyses the dimension occupied by African affairs in Brazil during the Lula era. The main argument is that the new role played by Africa in the international scene coincides with a global Brazil.
\end{abstract}

\section{Resumo}

No mundo pós-Guerra Fria, a África tem tido um papel de destaque para política externa brasileira. Além de ter significativo peso histórico na formação da nação, os países africanos também são parte do movimento adotado pela política externa brasileira. O propósito central deste texto é mostrar essa dimensão regional relevante da inserção internacional do Brasil na era Lula. O trabalho está dividido em duas partes: a primeira versa sobre a inserção internacional da África em anos recentes e a segunda analisa a dimensão ocupada pelo continente na política externa brasileira. O argumento central é que o novo lugar ocupado pela África no cenário internacional coincide com o Brasil global.

Key-words: Brazilian foreign policy; African continent; Brazilian Atlantic Policy.

Palavras-chave: política externa brasileira; continente Africano; Política atlântica brasileira. 